\title{
O ESTADO ATUAL DA REGULAMENTAÇÃO DA GESTAÇÃO DE SUBSTITUIÇÃO: UM OLHAR SOBRE A ATIVIDADE LEGISLATIVA DO CONGRESSO NACIONAL
}

\author{
THE CURRENT STATUS OF SURROGACY REGULATION: AN \\ OUTLOOK OVER THE LAWMAKING ACTIVITY OF BRAZIL'S \\ NATIONAL CONGRESS
}

Vinícius Périssé Maia Veras

\begin{abstract}
RESUMO
O presente artigo estuda, por meio de dados quantitativos e qualitativos, a atividade legislativa do Congresso Nacional acerca da gestação de substituição. A única norma existente sobre o tema é a Resolução n 2168/2017, do Conselho Federal de Medicina, o que justifica a realização deste estudo. Foi analisado o conteúdo jurídico dos projetos de lei presentes nos sítios eletrônicos de ambas as Casas do Congresso Nacional que mencionam expressamente a gestação de substituição. Descobriu-se que existem 11 projetos com essas características nos arquivos eletrônicos da Câmara dos Deputados. Os projetos de lei estudados, bem como a referida resolução do CFM, possuem diversos pontos de constitucionalidade questionável. Concluiu-se que a discussão sobre gestação de substituição no Congresso Nacional ainda se encontra em estado aquém do adequado à concretização do direito ao livre planejamento familiar.
\end{abstract}

Palavras-chave: Gestação de Substituição. Planejamento Familiar. Congresso Nacional.

\begin{abstract}
This article studies, through quantitative and qualitative data, the lawmaking activity of the National Congress about surrogacy. The only existing norm on the subject is the Resolution No. 2168/2017 of the Federal Council of Medicine, which justifies this study. The legal content of the bills present in the websites of both houses of the National Congress that expressly mention surrogacy was analysed. It turned out that there are 11 projects with these characteristics in the electronic archives of the House of Representatives. The studied bills, as well as the mentioned FCM resolution, have several points of questionable constitutionality. It was concluded that the discussion on surrogacy in the National Congress is still in a state that is not adequate to the realization of the right to free family planning.
\end{abstract}

Keywords: Surrogacy. Family Planning. National Congress.

\section{INTRODUÇÃO}

Nos últimos anos, a reprodução assistida (RA) tem se consolidado como parte do cotidiano brasileiro. Da mesma forma, ganha importância também o acordo de gestação de substituição, processo auxiliar às técnicas de RA. Entretanto, a despeito da crescente presença deste fenômeno e das incontáveis controvérsias bioéticas que ele suscita, não existe, no ordenamento jurídico pátrio, qualquer tipo de regulamentação das técnicas de RA por meio de lei. 
Atualmente, a única regulamentação disponível sobre o tema é a Resolução 2168/2017 do Conselho Federal de Medicina (CFM). Ressalta-se, entretanto, que as normas dessa resolução são meramente deontológicas, não possuindo qualquer coercitividade jurídica. Isso se torna problemático, na medida em que essas normas não seriam capazes, por si só, de coibir abusos e má-utilização das técnicas de reprodução assistida.

Além disso, como se discutirá abaixo, é possível notar diversos pontos de constitucionalidade questionável na resolução do CFM, como as suas limitações em razão da idade e do parentesco, que atentam contra a Autonomia, elemento inerente à Dignidade da Pessoa Humana, positivada no Artigo 1º inc. III, da Constituição Federal de 1988. Diante desse cenário, fica clara a relevância de se voltar os olhos à discussão sobre reprodução assistida no Congresso Nacional.

E é justamente a isso que o presente trabalho se propõe: conhecer, por meio de dados quantitativos e qualitativos, a atividade legislativa do Congresso Nacional acerca da Gestação de Substituição, bem como identificar as possíveis causas para a inexistência de regulação por meio de lei strictu sensu e utilizar os dados obtidos para promover discussões relevantes acerca das consequências jurídicas e práticas dessa ausência de regulação.

Quanto à metodologia desta pesquisa, foi levantada ampla bibliografia sobre o tema em debate e coletadas informações sobre projetos de lei em tramitação no Congresso Nacional. A coleta de dados foi realizada durante o período de 3 de outubro de 2018 a 31 de dezembro de 2018. Portanto, foram considerados os projetos existentes, bem como seus diferentes estágios de tramitação, até esta última data. Todos os dados foram retirados dos sítios eletrônicos de ambas as Casas do Congresso Nacional.

Primeiramente, foram agrupados em planilha eletrônica todos os projetos de lei disponíveis nos sites do Congresso Nacional que tratam da Reprodução Assistida. Em seguida, foram selecionados aqueles que mencionam expressamente a técnica de Gestação de Substituição. Foi analisado o conteúdo jurídico de cada um desses projetos, bem como as justificativas fornecidas pelos seus autores e votos de relatores em comissões. Por fim, os dados obtidos foram concentrados para possibilitar uma visão ampla sobre o panorama da discussão legislativa sobre a Gestação de Substituição.

Como referencial teórico para este trabalho, são utilizadas as reflexões promovidas por Beatriz Schettini: o direito ao uso das técnicas de RA faz parte do conteúdo do Planejamento Familiar (Artigo 226, $\S 7^{\circ}$, Constituição Federal). Este é um direito 
fundamental e, em razão disso, um direito subjetivo, capaz de fundamentar pretensões judiciais. O Planejamento Familiar deve ser exercido mediante limites impostos pela própria Constituição. ${ }^{1}$

\section{A GESTAÇÃO DE SUBSTITUIÇÃO}

Diante da dificuldade técnica inerente ao objeto de estudo, faz-se necessário apontar algumas diferenciações terminológicas. Primeiro, há de se compreender que a reprodução assistida é um conjunto de técnicas médicas que buscam viabilizar a reprodução humana. Fazem parte deste variado conjunto procedimentos como a relação programada, a inseminação artificial intrauterina e a fertilização in vitro. Portanto, a RA é a intervenção humana no processo de procriação natural, com o objetivo de possibilitar que pessoas que sofrem de infertilidade ou esterilidade satisfaçam o desejo de alcançar a maternidade ou paternidade. $^{2}$

Por sua vez, a gestação de substituição não deve ser considerada como uma técnica de RA. De forma diversa, ela funciona como um processo auxiliar a essas técnicas. Tratase, na verdade, de uma relação em que são partes uma mulher e normalmente seu esposo ou companheiro, que, fornecedor ou não do material genético, deseja ter um filho, e a outra mulher, que por dinheiro ou altruísmo, cederá temporariamente seu útero para que nele seja gesta a criança até o parto, entregando-lhe àquela. ${ }^{3}$

Existem diversas denominações para este procedimento, como "barriga de aluguel”, "mãe de aluguel”, "maternidade de sub-rogação" entre outros. Os termos utilizados neste trabalho são "cessão temporário do útero" e "gestação de substituição", ambos adotados pelo CFM na Resolução 2168/2017.

Eleonora Lamm chama a atenção para o fato de que diversas definições para a gestação de substituição surgiram e foram se modificando à medida em que avançava $o$ progresso científico sobre o tema. Com base nas lições da autora espanhola, pode-se descrever o procedimento da gestação de substituição da seguinte forma: uma pessoa

1 SCHETTINI, Beatriz. Planejamento familiar e a gestação de substituição: os limites ao exercício do direito de procriação. In: RODRIGUES JÚNIOR, Walsir Edson (Org.). Direito das famílias: novas tendências. Belo Horizonte: D’Plácido, 2015. p. 31-48, p.46.

2 MALUF, Adriana Caldas do Rego Freitas Dabus. Curso de Bioética e Biodireito. 3 ed. São Paulo: Atlas, 2015, p.193.

3 MALUF, idem, p.227. 
(gestante) acorda com outra pessoa, ou com uma parente (cliente), gestar um embrião com o fim de que a criança nascida tenha vínculos jurídicos de filiação com a cliente. ${ }^{4}$

Na doutrina brasileira, Rodrigues, Moreira, Ribeiro e Cabral apresentam definição completa e sintética:

\begin{abstract}
A maternidade de sub-rogação consiste na inseminação artificial de material genético em uma mulher, que, por solicitação de outra, empresta o útero temporariamente para gerar a criança, sendo esta parenta consanguínea até o quarto grau, devendo entregar a criança ao nascer para a pessoa solicitante. Trata-se de um procedimento da reprodução humana assistida, em que há a substituição da relação sexual por procedimentos laboratoriais, que serão feitos por profissionais de equipe médica, ao fazerem a junção do sêmen com o óvulo. ${ }^{5}$
\end{abstract}

A partir da Resolução 2168/2017, CFM, é possível afirmar que, independentemente da definição adotada, a gestação de substituição será caracterizada pela presença de determinados fatores: (a) um casal ou indivíduo (doador genético) que não pode gestar, ou para o qual a gestação seja contraindicada; (b) uma mulher (cedente) que receberá o material genético para gerar a criança; (c) a ausência de vínculo jurídico entre a cedente e a criança gestada.

Como já explicitado, não há nenhuma regulamentação abrangente sobre RA com força de lei. Na legislação civil, a única disposição disponível são os tímidos incisos III, IV e V do Artigo 1597, do Código Civil. Na prática, servem apenas para produzir uma presunção de paternidade, não possuindo maior relevância para a regulamentação das RA.

Diante da incidência muito reduzida desses incisos, as normas da Resolução 2168/2017 continuam sendo a única regulamentação disponível sobre RA. Elas não são normas jurídicas, propriamente, mas sim normas deontológicas. Isso significa que não possuem coercitividade ou aplicação direta em demandas judiciais. Sua aplicação se restringe a fundamentar punições de profissionais e estabelecimentos médicos na esfera administrativa e a servir de parâmetros de decisão para o juiz, quando se tratar de litígio judicial.

Entre as regras mais importantes, previstas nos itens I, II e VII da Resolução 2168/2017, é possível destacar: (a) os beneficiários da técnica (doadores genéticos) devem sofrer de problema médico que impeça ou contraindique a gestação, ou estar em união estável homoafetiva ou ser pessoa solteira; (b) - a gestante (cedente temporária do

4 LAMM, Eleonora. Gestación por sustitución: ni maternidade subrogada ni alquiler de vientres. Barcelona: Universitat de Barcelona Publicacions i Edicions, 2014, p.24.

5 RODRIGUES, Daiany da Silva et al. A Cessão Temporária do Útero: análise de limitação etária de 50 anos para a cedente. Revista Nacional de Direito de Família e Sucessões, Porto Alegre, n. 21, p.61-79, nov. 2017, p.77 
útero) deve pertencer à família de um dos parceiros, em parentesco consanguíneo de até o quarto grau; (c) - a gestação de substituição não pode ter caráter lucrativo; (d) - é obrigatória a aprovação do cônjuge, por escrito, se a cedente for casada ou viver em união estável; (e) - a cedente não pode ter mais de 50 anos de idade.

Por fim, há de se destacar que a problemática da gestação de substituição é um tema cuja relevância transcende a Ciência Médica. A incapacidade de gerar filhos, seja por infertilidade ou esterilidade, sempre foi uma questão extremamente relevante para a humanidade. A busca pela procriação tem raízes biológicas que tornam extremamente frustrante a impossibilidade de ter filhos. O biólogo Robin Baker explica que ter filhos um instinto humano básico, programado por 400 bilhões de anos de evolução. Cada pessoa seria a representação atual de sua linhagem pessoal e única, que se estende para trás por incontáveis gerações. Não seria, portanto, de se estranhar que, a partir do momento da concepção, os genes humanos têm também produzido exaustivamente instruções para uma anatomia, uma química e um comportamento que incentivam a procriação. $^{6}$

Há evidências que demonstram a utilização da técnica de gestação de substituição como uma forma de "vencer" a infertilidade desde os chamados tempos bíblicos. É o que se verifica com a passagem descrita em Gênesis, capítulo 16, versículos 1 a 6:

Gênesis 16:1-6: Sarai , mulher de Abrão, não lhe tinha dado filhos; mas, possuindo uma escrava egípcia, chamada Agar, disse a Abrão: "eis que o Senhor me fez estéril; rogo-te que tomes a minha escrava para ver se ao menos por ela, eu posso ter filhos." Abrão aceitou a proposta de Sarai. Sarai tomou, pois, sua escrava, Agar, a egípcia, passados dez anos que Abrão habitava a terra de Canaã, e deu-a por mulher a Abrão, seu marido. Este aproximou-se de Agar e ela concebeu. Agar, vendo que tinha concebido, começou a desprezar a sua senhora. Então Sarai disse a Abrão: "Caia sobre ti o ultraje que me é feito" Dei-te minha escrava e ela, desde que concebeu, olha-me com desprezo. O Senhor seja juiz entre mim e ti!" Abrão respondeu-lhe: "Tua escrava está em teu poder, faze dela o que quiseres". E Sarai maltratou-a de tal forma que ela teve de fugir. ${ }^{7}$

A existência de relatos sobre versões rudimentares da gestação de substituição, datados de muitos séculos atrás, evidencia que tal acordo já é do conhecimento humano há tempos.

O surgimento precoce da técnica de gestação de substituição pode ser explicado pela já referida relevância da infertilidade para humanidade. Como visto, a infertilidade

6 BAKER, Robin. Sexo no Futuro: anseios ancestrais e novas tecnologias. Rio de Janeiro: Record, 2002, p.101.

7 BÍBLIA, A.T. Gênesis. In: Bíblia. Português. Bíblia Sagrada. Tradução portuguesa da versão francesa dos originais grego, hebraico e aramaico, traduzidos pelos Monges Beneditinos de Maredsous. São Paulo: Ave Maria, 2006, p.61. 
sempre fora um problema de ordem biológica, que gera frustração ao indivíduo que se vê incapacitado de atender aos seus instintos mais elementares.

Ao longo dos séculos, a percepção social sobre a infertilidade ou esterilidade mudou radicalmente. Passou de uma maldição divina, que recaía exclusivamente sobre a mulher, para um defeito biológico, capaz de se manifestar tanto em homens quanto em mulheres. ${ }^{8}$

Na atualidade, o Direito, especialmente o Direito de Família, vem enfrentando diversas situações inéditas em razão dos recentes avanços na biotecnologia. A popularização das técnicas de RA e da gestação de substituição põe em xeque conceitos há muito estabelecidos.

Tome-se por exemplo a própria presunção de que a mãe de uma criança é sempre aquela que lhe deu à luz: diante de uma situação de gestação de substituição, a mulher que gerou a criança (cedente) não terá qualquer vínculo parental com o nascituro. Este vínculo será formado entre o infante e a contratante da barriga de aluguel (doadora genética). Logo, não seria possível aplicar a presunção de filiação tradicional.

Também cai por terra o modelo único de família, caracterizado pelo matrimônio entre indivíduos de sexos diferentes, hierarquização e presunções de paternidade. A gestação de substituição, aliada às demais técnicas de RA, permite a criação de projetos de filiação monoparentais e também homossexuais.

Diante dessas mudanças no perfil da instituição familiar, é necessário que o Direito se atualize para atender às novas demandas em respeito aos mais caros valores constitucionais, como a Dignidade da Pessoa Humana (Artigo $1^{\circ}$, III) e o Direito ao Livre Planejamento Familiar (Artigo 226, $\S 7^{\circ}$ ).

Schettini explica que o Direito de Família tem se deparado com possibilidades até pouco tempo desconhecidas e inesperadas, como o surgimento da prova pericial, através do DNA, bem como a possibilidade de concepção de um filho fora da relação sexual, pela gestação de substituição. Tais possibilidades revolucionaram não só aspectos jurídicos, mas também a própria concepção de família, ou seja, os avanços científicos e tecnológicos, especialmente no que diz respeito às técnicas médicas utilizadas para a

8 RODRIGUES, Daiany da Silva et al. A Cessão Temporária do Útero: análise de limitação etária de 50 anos para a cedente. Revista Nacional de Direito de Família e Sucessões, Porto Alegre, n. 21, p.61-79, nov. 2017, p.64. 
reprodução humana, têm demonstrado a necessidade de repensar conceitos antes preestabelecidos e considerados incontestáveis. ${ }^{9}$

\section{A ATIVIDADE LEGISLATIVA DO CONGRESSO NACIONAL}

Existem 11 projetos nos arquivos eletrônicos da Câmara dos Deputados que tratam expressamente da Gestação de Substituição. Entre os 11, cinco proíbem total ou parcialmente o uso desta técnica. Os demais a permitem, porém com uma série de restrições, em geral, idênticas às da Resolução 2168/2017, do Conselho Federal de Medicina, que é, ao tempo da confecção deste trabalho, a única regulação das técnicas de RA existente no Brasil.

Começando-se pelos projetos que proíbem a gestação de substituição, tem-se o PL 809/1991, de autoria do então Deputado Federal Maurici Mariano, à época, integrante do Partido da Reconstrução Nacional (PRN $)^{10}$. O texto proíbe o implante de embrião humano em mulher que não seja a própria geradora genética, criminalizando a gestação de substituição, à ameaça de pena de detenção, de seis meses a dois anos e multa. Sendo realizado o procedimento, o PL determina que a responsável pela gestação será a mãe, desde que requeira até trinta dias após o nascimento da criança. ${ }^{11}$

O PL 1645/1991, confeccionado pelo Deputado Federal Nilson Gibson, à época no Partido do Movimento Democrático Brasileiro (PMDB) $)^{12}$, veda a cessão do útero para fins de concepção por intermédio de inseminação artificial. A pena para a cessão seria de reclusão, de dois a cinco anos. O projeto ressalva, entretanto, que o crime não deve abranger as situações em que o sêmen vem do próprio cônjuge ou companheiro, ou de descendente, na linha reta ou colateral consanguínea ou afim, até o terceiro grau. ${ }^{13}$

O PL 1737/1991, cujo autor é o então Deputado Federal Osmanio Pereira, à época no Partido Social Democrata Brasileiro (PSDB), criminaliza a doação de embriões e os

9 SCHETTINI, Beatriz. Planejamento familiar e a gestação de substituição: os limites ao exercício do direito de procriação. In: RODRIGUES JÚNIOR, Walsir Edson (Org.). Direito das famílias: novas tendências. Belo Horizonte: D’Plácido, 2015. p. 31-48, p.33.

10 Atual Partido Trabalhista Cristão.

11 BRASIL. Câmara dos Deputados. Projeto de lei. PL 809/1991. Disponível em: https://www.camara.leg.br/proposicoesWeb/prop_mostrarintegra;jsessionid=EA45406585FE945577B B9BBE2C8E2966.proposicoesWebExterno1?codteor=1144316\&filename=Dossie+-PL+809/1991. Acesso em: 19 jul. 2019.

12 Atual Movimento Democrático Brasileiro.

13 BRASIL. Câmara dos Deputados. Projeto de lei. PL 1645/1991. Disponível em: https://www.camara.leg.br/proposicoesWeb/prop_mostrarintegra?codteor=1144490\&filename=Dossie +-PL+1645/1991. Acesso em: 19 jul. 2019. 
contratos de procriação ou de gestação por conta de outrem. Não menciona, entretanto, qualquer penalidade para a prática desses procedimentos. ${ }^{14}$

O PL 6296/2002, do autor Deputado Federal Magno Malta, do Partido Liberal $(\mathrm{PL})^{15}$, proíbe a fertilização de óvulos humanos com material genético provenientes de células de doador do gênero feminino. Determina que a desobediência a essas normas sujeita o infrator à pena prevista no Art.13, II, da Lei 8.974, de 5 de janeiro de $1995 .{ }^{16}$

Por fim, o PL 1184/2003, de autoria do Deputado Federal Lúcio Alcântara, à época no PSDB, criminaliza a Gestação de Substituição, sob pena de reclusão de um a três anos e multa. ${ }^{17}$

Adentrando-se nos projetos que permitem a gestação de substituição, tem-se que o PL 2061/2003, de autoria da Deputada Federal Maria José Conceição, à época no Partido dos Trabalhadores (PT). O projeto permite a gestação de substituição, desde que exista um problema médico que impeça ou contraindique a gestação na doadora genética. Por outro lado, veda qualquer caráter lucrativo ou comercial. ${ }^{18}$

O PL 3638/1993, de autoria do Deputado Federal Luiz Moreira, do Partido Trabalhista Brasileiro (PTB), autoriza a Gestação de Substituição, desde que exista um problema médico que impeça ou contraindique a gestação na doadora genética. Também exige que a doadora do útero pertença à família da doadora genética, com parentesco até o segundo grau, e que a doação tenha caráter gratuito. ${ }^{19}$

O PL 1135/03, de autoria do Deputado Federal Dr. Pinotti, do Partido do Movimento Democrático Brasileiro (PMDB), traz regras muito semelhantes ao anterior, sem nenhuma grande peculiaridade..$^{20}$

14 BRASIL. Câmara dos Deputados. Projeto de lei. PL 1737/1991. Disponível em: https://www.camara.leg.br/proposicoesWeb/prop_mostrarintegra?codteor=1141638\&filename=Dossie +-PL+1737/1991. Acesso em: 19 jul. 2019.

15 Não mais existente.

16 BRASIL. Câmara dos Deputados. Projeto de lei. PL 6296/2002. Disponível em: https://www.camara.leg.br/proposicoesWeb/prop_mostrarintegra?codteor $=1281277 \&$ filename $=\mathrm{PL}+62$ 96/2002. Acesso em: 19 jul. 2019.

17 BRASIL. Câmara dos Deputados. Projeto de lei. PL 1184/2003. Disponível em: https://www.camara.leg.br/proposicoesWeb/prop_mostrarintegra?codteor $=137589 \&$ filename $=P L+118$ 4/2003. Acesso em: 19 jul. 2019.

18 BRASIL. Câmara dos Deputados. Projeto de lei. PL 2061/2003. Disponível em: https://www.camara.leg.br/proposicoesWeb/prop_mostrarintegra?codteor $=166567 \&$ filename $=P L+206$ 1/2003. Acesso em: 19 jul. 2019.

19 BRASIL. Câmara dos Deputados. Projeto de lei. PL 3638/1993. Disponível em: http://imagem.camara.gov.br/Imagem/d/pdf/DCD30MAR1993.pdf\#page=35. Acesso em: 20 jul. 2019.

20 BRASIL. Câmara dos Deputados. Projeto de lei. PL 1135/2003. Disponível em: https://www.camara.leg.br/proposicoesWeb/prop_mostrarintegra?codteor $=136097 \&$ filename $=P L+113$ 5/2003. Acesso em: 20 jul. 2019. 
O PL 115/2015, do Deputado Federal Juscelino Rezende Filho, do Partido Republicano Progressista (PRP) ${ }^{21}$, estabelece normas gerais quase iguais ao anterior, porém determinando a obrigatoriedade de homologação judicial do acordo de gestação de substituição. Outra peculiaridade a ser apontada é que o PL lista uma série de princípios a serem aplicados no tratamento da gestação de substituição: Respeito à vida humana; Serenidade Familiar; Igualdade; Dignidade da Pessoa Humana; Superior interesse do menor; Paternidade responsável; Liberdade de planejamento familiar; Proteção integral da família; Autonomia da vontade; Boa-fé objetiva; Transparência; Subsidiariedade. ${ }^{22}$

O PL 4892/2012, do autor Deputado Federal Euleses Vieira de Paiva, do Partido Social Democrático (PSD), tem regras idênticas às do PL 115/15, inclusive quanto à obrigatoriedade de homologação judicial do acordo de gestação de substituição e a proteção principiológica. ${ }^{23}$

Por fim, o PL 2855/97, do autor Deputado Federal Confúcio Aires Moura, à época no PMDB, permite a gestação de substituição em caso de impossibilidade de gestação pela mãe legal por defeito congênito ou adquirido. Veda também a doação temporária onerosa.

\section{A INEXISTÊNCIA DE LEI REGULAMENTADORA}

A partir dos dados colhidos, foi possível levantar três possíveis motivos para a ausência de projetos aprovados: forte controvérsia religiosa; necessidade de participação efetiva da sociedade na tomada de decisão; posição de deferência do Poder Legislativo ao Conselho Federal de Medicina.

A possibilidade de fatores religiosos, especialmente de matriz cristã, influenciarem na demora para a aprovação dos projetos vem do seguinte fato: dos 5 projetos que proíbem a gestação de substituição, 2 citam argumentos religiosos em suas justificativas. Isso demonstra que o tema em questão suscita forte controvérsia de cunho religioso perante a

21 Atualmente incorporado ao Patriota.

22 BRASIL. Câmara dos Deputados. Projeto de lei. $P L$ 115/2015. Disponível em: https://www.camara.leg.br/proposicoesWeb/prop_mostrarintegra?codteor=1296985\&filename=PL+11 5/2015. Acesso em: 20 jul. 2019.

23 BRASIL. Câmara dos Deputados. Projeto de lei. PL 4892/2012. Disponível em: https://www.camara.leg.br/proposicoesWeb/prop_mostrarintegra;jsessionid=A61C326BD8AE11A34 9044D150C750ACF.proposicoesWebExterno1 ?codteor $=1051906 \&$ filename $=$ PL+4892/2012. Acesso em: 5 ago. 2019. 
sociedade, originando posições radicalmente contrárias à legalidade da gestação de substituição. É o que se pode verificar no caso dos PL 809/1991 e 1645/1991.

Na justificativa do PL 809/1991, o autor cita, entre seus argumentos, a necessidade de se conservar e priorizar a chamada "família tradicional brasileira". Como é sabido, a instituição a que o então deputado se refere é aquela da família heterossexual, nuclear, criada nos moldes dos tradicionais valores cristãos, amplamente enraizados na cultura brasileira. Tal linha de pensamento de cunho religioso e cultural é clara na seguinte passagem:

Por mais que se regulamente tal prática, sempre haverá a dúvida se foi correta a decisão tomada. Portanto, o melhor que se faz é evitar esta prática a bem da família brasileira, pois que em função de tais conflitos a mais prejudicada será a criança, que crescerá sob a influência da angústia vivida pela "Mãe de Aluguel" e pela pressão dos pais genéticos. ${ }^{24}$

Por sua vez, o PL 1645/1991 classifica expressamente a maternidade como realização divina da mulher, devendo esta, na concepção do autor, receber "a mais ampla proteção", que seria a vedação da gestação de substituição. O projeto chega ainda ao ponto extremamente controverso, especialmente sob uma perspectiva estritamente científica, de proibir a gestação de substituição, ressalvando apenas a hipótese em que o material genético masculino provém "do próprio marido ou companheiro ou de parentes próximos". Trata-se do exposto no seguinte trecho:

\begin{abstract}
A maternidade é a realização da mulher. É divina e deve merecer, dos poderes públicos, a mais ampla proteção. Por isso mesmo, a nossa sociedade tem recebido, com imensas reservas, o denominado "ventre de aluguel". (...) Este projeto veda a cessão do útero, para fins de inseminação artificial, fazendo ressalva apenas quando o sêmen for o do próprio marido ou companheiro ou de parentes próximos. ${ }^{25}$
\end{abstract}

A segunda possibilidade a ser enfrentada é a de que a inércia do Congresso se dá em razão do forte desacordo moral que a gestação de substituição suscita perante a sociedade. Esse desacordo, que gera posições radicalmente opostas e, em primeira análise, igualmente válidas sobre o tema, torna essencial a manifestação da opinião pública precedente à aprovação de qualquer projeto.

24 BRASIL. Câmara dos Deputados. Justificativa de Projeto de lei. PL 809/1991. Disponível em: https://www.camara.leg.br/proposicoesWeb/prop_mostrarintegra;jsessionid=34671860573DA42DD6 E233C65A454430.proposicoesWebExterno2?codteor=1144316\&filename=Dossie+-PL+809/1991. Acesso em: 19 jul. 2019.

25 BRASIL. Câmara dos Deputados. Justificativa de Projeto de lei. PL 1645/1991. Disponível em: https://www.camara.leg.br/proposicoesWeb/prop_mostrarintegra?codteor=1144490\&filename=Dossie +-PL+1645/1991. Acesso em: 19 jul. 2019. 
O instrumento mais adequado para esta consulta à opinião pública é a audiência pública. Entretanto, tal procedimento é demorado e custoso no sistema brasileiro, condenando-o a uma menor eficiência.

É possível verificar a incidência deste problema no caso do PL 1184/2003. Sua tramitação já se prolonga há mais de 15 anos e, ainda assim, aguarda desde agosto de 2015 a realização de uma audiência pública, pendência responsável pela falta de progresso nas discussões do Poder Legislativo.

Uma terceira razão seria a posição de deferência do Congresso Nacional perante os órgãos técnicos, no caso, o Conselho Federal de Medicina. Isso significaria que o Congresso dá preferência às conclusões do CFM quanto ao conteúdo da regulamentação sobre gestação de substituição, o que levaria à inércia do Legislativo, em razão da existência de resoluções já produzidas pelo órgão técnico em questão.

De fato, o tema da gestação de substituição é extremamente técnico e delicado do ponto de vista biomédico. As técnicas de RA ainda se encontram em evolução, de forma que um debate qualificado sobre elas é extremamente difícil, especialmente se a opinião pública for diretamente considerada para a produção de uma lei sobre o tema em estudo.

As evidências para essa terceira razão se encontram em todos os projetos que permitem a Gestação de Substituição, pois todos trazem regras muito semelhantes ou realmente idênticas às da Resolução 2168/2017, do CFM.

Tome-se por exemplo o conteúdo do PL 2061/2003: as técnicas de RA só podem ser usadas quando houver probabilidade efetiva de sucesso e ausência de risco grave de saúde para a mulher e para o nascituro (Art. $2^{\circ}$ ); é obrigatório o consentimento informado, por escrito (Art. $4^{\circ}$ ); é proibida a fecundação com qualquer outra finalidade que não seja a procriação humana (Art.6 ${ }^{\circ}$ ); são beneficiários das técnicas pessoas capazes que informaram seu livre consentimento de forma escrita (Art. $8^{\circ}$ ); é permitida a gestação de substituição desde que exista um problema médico que impeça ou contraindique a gestação na doadora genética (Art.13, caput); é vedada a onerosidade no acordo de gestação de substituição (Art.13, parágrafo único).

O PL 2061/2003 traz regras muito semelhantes, ou mesmo idênticas às já aplicadas há anos pelo Conselho Federal de Medicina, repetidas ou atualizadas na Resolução 2168/2017, em seus itens I, II e VII. Dessa forma, é possível notar que a posição de deferência do Congresso Nacional em relação ao CFM pode gerar dois efeitos: a não produção de lei, em favor da manutenção das normas do CFM, ou a produção de PLs com conteúdo baseado (ou mesmo idêntico) nas normas já criadas pelo Conselho. 
Incorrendo uma pluralidade de fatores, não é possível apontar qual dos três seria determinante para a demora na produção de uma lei que regulamente a gestação de substituição. A conclusão mais sólida é no sentido de que a inércia do Congresso Nacional se dá em razão da combinação dos três fatores. Não há lei até o presente momento porque a gestação de substituição é um tema que: (i) suscita forte controvérsia de cunho religioso e cultural; (ii) necessita de efetiva consulta à opinião pública para ter o devido lastro democrático; (iii) se mostra extremamente técnico, o que leva os parlamentares a dar preferência às normas editadas pelo Conselho Federal de Medicina, seja conservando as suas resoluções como a única regulamentação ou propondo projetos de lei que trazem conteúdo idêntico a tais resoluções.

Outro tema que precisa ser enfrentado, como um desdobramento do tópico anterior, é a insuficiência das normas do Conselho Federal de Medicina no atendimento aos valores constitucionais, especialmente da Dignidade da Pessoa Humana e do Direito ao Livre Planejamento Familiar. Existem diversos pontos passíveis de questionamento na Resolução 2168/2017, de forma que a semelhança de conteúdo apresentada por boa parte dos projetos de lei abordados neste estudo pode implicar em limitação injustificada de direitos fundamentais.

Como explicitado supra, o presente estudo se baseia em duas premissas: primeiro, que o amplo acesso às técnicas de RA, incluindo a gestação de substituição, faz parte do conteúdo do Direito ao Livre Planejamento Familiar; segundo, que o Direito ao Livre Planejamento Familiar (Art.226, §7º, Constituição Federal de 1988) possui status de direito fundamental.

Tratando-se de um direito fundamental, a atuação da Administração Pública no âmbito do Planejamento Familiar se sujeita aos chamados limites dos limites, expressão que designa os diversos obstáculos normativos que restringem a possibilidade de o Poder Público limitar os Direitos Fundamentais ${ }^{26}$

O primeiro limite dos limites a ser analisado é o da reserva de lei, que significa a impossibilidade de a Administração Pública adotar medidas restritivas de direitos sem fundamento legal ou constitucional ${ }^{27}$. Sob essa perspectiva, a Administração Pública não

26 PEREIRA, Jane Reis Gonçalves. Interpretação Constitucional e Direitos Fundamentais. 2. ed. São Paulo: Saraiva Educação, 2018, p.340.

27 PEREIRA, Jane Reis Gonçalves. Interpretação Constitucional e Direitos Fundamentais. 2. ed. São Paulo: Saraiva Educação, 2018, p.348. 
pode, por seu próprio atuar, limitar direitos fundamentais, mas apenas satisfazer as previsões estatuídas na legislação que restringe esses direitos.

Por possuir natureza jurídica de autarquia (Art. $1^{\circ}$, Lei n 3.268/1957), o Conselho Federal de Medicina faz parte da Administração Pública Indireta. Também por essa razão, seus atos normativos se sujeitam à mencionada reserva de lei. Dessa forma, uma vez caracterizada a limitação do Direito ao Livre Planejamento Familiar, a Resolução 2168/2017 incorre em restrição inconstitucional de direito fundamental.

Como se demonstra infra, as normas do CFM implicam em limitação do Direito ao Livre Planejamento Familiar, o que seria vedado pela reserva de lei. Tal problema poderia ser resolvido com a criação de lei que regulamentasse a gestação de substituição e revogasse a Resolução 2168/2017. Entretanto, ainda que resolvida a questão relacionada à reserva de lei, a nova legislação ainda precisaria passar pelo crivo de outro limite dos limites, qual seja, o Princípio da Proporcionalidade.

O presente trabalho se abstém de explorar a extensa controvérsia acerca da fundamentação e do significado do referido princípio, por se afastar demais do objeto de estudo. Por essa razão, adota-se as ponderações feitas por Jane Reis Gonçalves Pereira sobre o tema ${ }^{28}$.

Ainda que os PLs analisados, uma vez convertidos em lei, resolvessem a questão da reserva de lei, determinadas disposições não seriam permitidas na ordem constitucional brasileira, em razão de ofensa ao Princípio da Proporcionalidade. Tal princípio se divide em três subprincípios, que representam etapas na análise de proporcionalidade de um ato normativo: Princípio da Idoneidade, Princípio da Necessidade e Princípio da Proporcionalidade em sentido estrito.

O Princípio da Idoneidade exige que toda restrição aos direitos fundamentais seja idônea para o atendimento de um fim constitucionalmente legítimo ${ }^{29}$. No preâmbulo da Resolução 2168/2017, o CFM lista como uma das justificativas para o ato normativo a legitimidade do anseio de superar a infertilidade humana, considerada como um problema de saúde, com implicações médicas e psicológicas. Portanto, é possível afirmar que os fins constitucionalmente legítimos que a resolução se propõe a cumprir são o Direito à Saúde (Art.6 ${ }^{\circ}$, Constituição Federal de 1988) e à Integridade Psicofísica. ${ }^{30}$

28 PEREIRA, idem, p.359-402.

29 PEREIRA, idem, p.363.

30 Tal direito, embora não previsto expressa e autonomamente na Constituição Federal, pode ser deduzido a partir de alguns de seus dispositivos, como o inciso XLIX, do Art. $5^{\circ}$. 
O Princípio da Necessidade preconiza que, dentre as várias medidas restritivas de direitos fundamentais igualmente aptas a atingir o fim perseguido, a Constituição impõe que o legislador opte por aquela menos lesiva para os direitos ${ }^{31}$. Por sua vez, o Princípio da Proporcionalidade em sentido estrito determina que uma restrição a direitos fundamentais é constitucional se pode ser justificada pela relevância do princípio cuja implementação é buscada por meio da intervenção ${ }^{32}$.

Estabelecidas as premissas sobre o Princípio da Proporcionalidade, deve-se analisar as principais medidas propostas pela Resolução 2168/2017, repetidas ou não nos PLs destacados, que possivelmente atentam contra o referido princípio.

Primeiramente, merece destaque a limitação de idade para a cedente em cinquenta anos. Segundo Rodrigues, Moreira, Ribeiro e Cabral, as justificativas oferecidas pelo Conselho Federal de Medicina para a instituição de tal regra se baseiam no fato de que, na fase da vida, as mulheres estão mais vulneráveis a doenças, levando-se em consideração que estariam já em período de menopausa, ou prestes a entrar nele. Além disso, alega-se que gerar uma criança nessa faixa de idade pode gerar grandes riscos, tanto para a mulher (hipertensão, diabetes etc.) como para a criança (nascimento prematuro e com baixo peso). ${ }^{33}$

Entretanto, como as autoras demonstram, a chegada à idade de cinquenta anos não importa, necessariamente, na perda da saúde necessária para se carregar uma gestação. Atualmente, existem muitas mulheres com mais de cinquenta anos que se encontram com uma saúde em perfeito estado, dispondo de condições suficientes para gerar, até mais que algumas mulheres mais jovens que sofrem de certas patologias. Portanto, a impossibilidade de uma mulher gerar nada mais é do que uma questão de saúde, visto que a gestação sempre ocorre de um ato natural, então, cabe ao Estado proporcionar o direito à saúde a mulheres que sofrem de infertilidade. ${ }^{34}$

Dessa forma, há de se concluir que a resolução do CFM, ao restringir o uso das técnicas de RA para mulheres acima de 50 anos, afronta os direitos indisponíveis, não considerando a liberdade do projeto parental.

\footnotetext{
31 PEREIRA, Jane Reis Gonçalves. Interpretação Constitucional e Direitos Fundamentais. 2. ed. São Paulo: Saraiva Educação, 2018, p.374.

32 PEREIRA, idem, p.381.

33 RODRIGUES, Daiany da Silva et al. A Cessão Temporária do Útero: análise de limitação etária de 50 anos para a cedente. Revista Nacional de Direito de Família e Sucessões, Porto Alegre, n. 21, p.61-79, nov. 2017, p.73.

34 RODRIGUES, idem, p.76.
} 
Passa-se, portanto, à análise de proporcionalidade da medida. $\mathrm{O}$ fim buscado pelo CFM é impedir que a gestante corra os riscos inerentes a uma gravidez em idade mais avançada, preservando sua saúde e integridade psicofísica. A vedação do uso das técnicas de RA por mulheres de idade superior a 50 anos serviria para impedir que elas se sujeitassem a esses riscos. Logo, pode-se afirmar que a medida é idônea para a concretização do objetivo do CFM.

Entretanto, há de se indagar se tal medida é necessária. Como visto, a norma do CFM é fundada em premissa que não se mostra mais verdadeira na atualidade, uma vez que mulheres de 50 anos, em grande parte, dispõem da saúde necessária para carregar a gestação. Dessa forma, ela acaba por atingir um número mais elevado de mulheres do que o realmente necessário, reduzindo seu gozo do direito ao Livre Planejamento Familiar. Não atendendo ao mandamento de que se opte pela limitação menos lesiva a direitos, tal medida se mostra desnecessária. Resta configurada, portanto, a desproporcionalidade da norma limitadora de cinquenta anos de idade.

Em sentido semelhante, conclui Rodrigues et al que a limitação de idade na gestação de substituição fere o princípio reprodutivo da mulher, a liberdade de escolha e o livre planejamento familiar, já que o texto constitucional prioriza a família como um instituto intocável, dando autonomia a cada membro para administrar o planejamento familiar. Assim, a limitação etária representaria um verdadeiro retrocesso aos direitos e garantias da pessoa humana. ${ }^{35}$

Também é possível chegar ao mesmo resultado por meio de argumentos fundados na Dignidade da Pessoa Humana (Art.1º, III, Constituição Federal de 1988). Não há consenso na doutrina ou na jurisprudência acerca de seu conteúdo ou sua forma de aplicação. Entretanto, um elemento essencial da dignidade que é listado pela grande maioria dos autores é a Autonomia. Define Luís Roberto Barroso:

\footnotetext{
"A autonomia é o elemento ético da dignidade humana. É o fundamento do livre-arbítrio dos indivíduos, que lhes permite buscar, da sua própria maneira, o ideal de viver bem e de ter uma vida boa. A noção central aqui é a de autodeterminação: uma pessoa autônoma define as regras que vão reger a sua vida." 36
}

Portanto, atentam contra a Dignidade da Pessoa Humana medidas normativas que violem ou reduzam injustificadamente a autonomia do indivíduo na construção do seu

35 RODRIGUES, Daiany da Silva et al. A Cessão Temporária do Útero: análise de limitação etária de 50 anos para a cedente. Revista Nacional de Direito de Família e Sucessões, Porto Alegre, n. 21, p.61-79, nov. 2017, p.78.

36 BARROSO, Luís Roberto. Curso de Direito Constitucional Contemporâneo: os conceitos fundamentais e a construção do novo modelo. 5. ed. São Paulo: Saraiva, 2015, p.167. 
próprio projeto de vida boa. Um dos principais riscos à Autonomia é o chamado paternalismo jurídico. Daniel Sarmento explica que o paternalismo, em sentido amplo, se baseia em uma analogia entre a relação do Estado com o indivíduo e aquela existente entre os pais e seus filhos. O paternalismo jurídico também se assenta na ideia de que, pelo menos em algumas situações, o Estado também sabe melhor o que é bom para cada pessoa do que ela mesma. Seus críticos o acusam de infantilizar os indivíduos, tratandoos como se não fossem capazes de tomar decisões apropriadas sobre as suas próprias vidas. Daí a sua tensão potencial com o princípio da dignidade da pessoa humana, que demanda que as pessoas sejam tratadas como sujeitos, e não como objetos da ação de terceiros, ainda que benevolente. ${ }^{37}$

Como visto, a Resolução do CFM confere "proteção" excessiva às pacientes de técnicas de RA, limitando desproporcionalmente o rol de possíveis beneficiárias. Apesar dos riscos normais de uma gravidez, acentuados pela idade, a limitação de idade proposta pelo CFM infantiliza as pacientes, determinando que elas não possam consentir com tais riscos. Portanto, uma legislação que se proponha a regulamentar a gestação de substituição, bem como as demais técnicas de RA, não pode impor um limite de idade de 50 anos.

Outras soluções poderiam ser utilizadas para cobrir os riscos gerados pelo avanço da idade. Por exemplo, cita-se a ampla descrição de tais riscos, com a propositura de termos de consentimento a serem assinados pela paciente. Uma vez que a relação médicopaciente é regida pelo Direito do Consumidor, é possível encontrar fundamento para a valorização do termo de consentimento no Princípio da Livre Escolha do Consumidor (Art.6 ${ }^{\circ}$, II, Código de Defesa do Consumidor). Dessa forma, a responsabilidade civil do médico teria como parâmetro a violação do dever de informar, por ferir a boa-fé, privando o paciente da possibilidade de exercer, de forma plena, sua liberdade de escolha. ${ }^{38}$

Além da limitação de idade, vale discorrer sobre a vedação à onerosidade do acordo de gestação de substituição, presente em todos os PLs que autorizam a referida técnica. Da mesma forma que o problema anterior, a vedação à onerosidade incorre em violação do elemento ético da Dignidade da Pessoa Humana. Dessa vez, entretanto, o risco advém do chamado moralismo jurídico, definido como a posição que preconiza a legitimidade

37 SARMENTO, Daniel. Dignidade da Pessoa Humana: conteúdo, trajetórias e metodologia. 2. ed. Belo Horizonte: Editora Fórum, 2016, p.170-171.

38 DALSENTER, Thamis; KONDER, Carlos Nelson. Questões atuais da responsabilidade civil médica e hospitalar. In: DADALTO, Luciana; TEIXEIRA, Ana Carolina Brochado (Orgs.). Dos Hospitais aos Tribunais. 1. ed. Belo Horizonte: Del Rey, 2013. p.463-498, p.494. 
de restrições à autonomia da pessoa, não apenas para proteger direitos de terceiros ou interesses do próprio indivíduo, mas também para assegurar a observância da moral. Ele pode se voltar à defesa de valores, compartilhados ou de princípios morais ditos "objetivos". 39

Deve ser rechaçada a interpretação que considera a cessão temporária do útero como uma hipótese de disposição onerosa de órgão. Primeiramente, porque tal prática não importa, necessariamente, em diminuição permanente da integridade corporal da cedente. Em segundo lugar, porque o Art.15 da Lei 9434/1997 limita-se a proibir a prática de compra e venda de tecidos, órgãos ou partes do corpo humano. O contrato de compra e venda pressupõe a cessão da propriedade do bem, representada pelo transplante do órgão, o que não ocorre no caso da gestação de substituição. No acordo de gestação de substituição, há meramente uma utilização temporária do útero da cedente para um determinado fim (gestar a criança da doadora genética), sem implicar na transferência de propriedade e, muito menos, na retirada do útero. Dessa forma, há de se concluir que a cessão temporária do útero não equivale à venda de órgãos, vedada pelo ordenamento jurídico brasileiro.

Não havendo impasses do ponto de vista jurídico-penal, a única justificativa possível para a vedação à onerosidade é a conservação da moral vigente, que rechaça tal prática. Como visto, o moralismo jurídico entra em choque com a Dignidade da Pessoa Humana, na medida em que limita gravemente a autonomia do indivíduo sem fundamento constitucional. Por essa razão, a vedação à onerosidade configura restrição infundada à autonomia da cedente, que se encontra impossibilitada de acordar qualquer tipo de remuneração pela árdua tarefa que realiza: a de carregar por cerca de nove meses a prole de outra pessoa.

No afã de evitar fraudes à norma proibitiva da onerosidade, o CFM ainda determina a necessidade de a gestante de substituição pertencer à família de um de um dos parceiros em parentesco consanguíneo até o quarto grau ${ }^{40}$, norma repetida em boa parte dos PLs analisados. O mesmo raciocínio sintetizado para a vedação da onerosidade vale para esta disposição: não há respaldo constitucional para tal limitação à fruição das técnicas de RA, por ofensa à Dignidade da Pessoa Humana, em sua dimensão de Autonomia.

39 SARMENTO, Daniel. Dignidade da Pessoa Humana: conteúdo, trajetórias e metodologia. 2. ed. Belo Horizonte: Editora Fórum, 2016, p. 176.

40 SCHREIBER, Anderson. Manual de Direito Civil Contemporâneo. São Paulo: Saraiva Educação, 2018, p.862. 


\section{CONSIDERAÇÕES FINAIS}

A discussão sobre a gestação de substituição ainda tem um longo caminho a ser percorrido. Após extensa argumentação, foi possível concluir que a regulamentação sobre a gestação de substituição feita pelo Conselho Federal de Medicina é insuficiente por dois motivos: a ausência de coercitividade jurídica de suas normas e a insuficiência da Resolução 2168/2017 em atender aos valores fundamentais do Livre Planejamento Familiar e da Dignidade da Pessoa Humana, especialmente em sua dimensão ética.

Mesmo os projetos de lei que tramitam ou tramitaram no Congresso Nacional padecem dos mesmos problemas. Os projetos que proíbem a gestação de substituição têm por efeito a negação de uma prestação exigível com base no Direito Fundamental ao Livre Planejamento, definido como a liberdade para constituir ou não uma família, podendo a pessoa utilizar de métodos contraceptivos ou conceptivos. ${ }^{41}$ Por essa razão, devem ser rechaçados.

Os projetos que admitem a gestação de substituição também se mostram insuficientes, na medida em que trazem regras semelhantes às da Resolução 2168/2017, que, como já demonstrado, não atende à plena realização do Planejamento Familiar e da Dignidade da Pessoa Humana no âmbito da reprodução humana.

Apesar do aparente progressismo, tais projetos ainda se mostram retrógados em diversos pontos. Por exemplo, nenhum deles lista expressamente, como beneficiários da técnica, os projetos familiares monoparentais e homoafetivos, o que poderia levar o intérprete a entender que a lei não abarca estes casos.

A obrigatoriedade da homologação judicial do acordo de gestação de substituição, tal como sugerido pelos PLs 115/2015 e 4892/2012, apesar de prover alguma segurança jurídica a mais para os possíveis envolvidos, poderia representar penoso entrave burocrático para a realização da gestação. Além disso, caso as estatísticas de uso das RA continuem a crescer, as homologações representarão um número muito extenso de processos desnecessários preenchendo ainda mais o já congestionado Poder Judiciário Brasileiro.

Por sua vez, a proteção principiológica, proposta pelos mesmos dois projetos, corre o risco de ser ineficiente ou mesmo contraproducente. Isso porque os PLs limitam-se a

41 SCHETTINI, Beatriz. Planejamento familiar e a gestação de substituição: os limites ao exercício do direito de procriação. In: RODRIGUES JÚNIOR, Walsir Edson (Org.). Direito das famílias: novas tendências. Belo Horizonte: D’Plácido, 2015. p. 31-48, p.35. 
simplesmente listar um rol de princípios já previstos na Constituição Federal de 1988 ou em outras leis, determinando sua incidência, sem sequer empregar esforços para o esclarecimento de seu conteúdo.

A aplicação de princípios como a Dignidade da Pessoa Humana, Superior Interesse do Menor e Paternidade Responsável já poderia ser deduzida a partir do Princípio da Interpretação Conforme a Constituição, que impõe a juízes e tribunais que interpretem a legislação ordinária de modo a realizar, da maneira mais adequada, os valores e fins

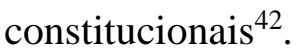

Somado a isso, não se pode ignorar as questões, já enfrentadas, acerca da limitação de idade para a cedente e da vedação à onerosidade. Tais normas, presentes na Resolução 2168/2017 e repetidas em boa parte dos PLs analisados, não se adequam aos Princípios Constitucionais que se quer realizar com a regulamentação da gestação de substituição, incorrendo em moralismo e paternalismo jurídicos.

Diante do exposto, é possível sintetizar os resultados do presente estudo nas seguintes conclusões: (a) não existe, até o momento atual, regulamentação do acordo de gestação de substituição por meio de lei; (b) a regulamentação dada pela Resolução $n^{\circ}$ 2168/2017, do Conselho Federal de Medicina, não concretiza a plenitude de direitos e valores constitucionalmente instituídos, como o Livre Planejamento Familiar e a Dignidade da Pessoa Humana; (c) a discussão sobre o tema no Congresso Nacional ainda se encontra aquém do necessário, como verificado nos PLs que proíbem a gestação de substituição, ou a permitem de forma quase idêntica à da Resolução no 2168/2017, do CFM.

\section{REFERÊNCIAS}

BAKER, Robin. Sexo no Futuro: anseios ancestrais e novas tecnologias. Rio de Janeiro: Record, 2002.

BARROSO, Luís Roberto. 'Aqui, lá e em todo lugar': a dignidade humana no direito contemporâneo e no discurso transnacional. Revista dos Tribunais, São Paulo, v. 919, p.127-196, maio 2012.

BARROSO, Luís Roberto. Curso de Direito Constitucional Contemporâneo: os conceitos fundamentais e a construção do novo modelo. 5. ed. São Paulo: Saraiva, 2015.

42 BARROSO, Luís Roberto. Curso de Direito Constitucional Contemporâneo: os conceitos fundamentais e a construção do novo modelo. 5. ed. São Paulo: Saraiva, 2015, p.336. 
BÍBLIA, A.T. Gênesis. In: Bíblia. Português. Bíblia Sagrada. Tradução portuguesa da versão francesa dos originais grego, hebraico e aramaico, traduzidos pelos Monges Beneditinos de Maredsous. São Paulo: Ave Maria, 2006.

BRASIL. Câmara dos Deputados. Justificativa de Projeto de lei. PL 809/1991. Disponível em:

https://www.camara.leg.br/proposicoesWeb/prop_mostrarintegra;jsessionid=346718605 73DA42DD6E233C65A454430.proposicoesWebExterno2?codteor=1144316\&filename =Dossie+-PL+809/1991. Acesso em: 19 jul. 2019.

BRASIL. Câmara dos Deputados. Justificativa de Projeto de lei. PL 1645/1991. Disponível em:

https://www.camara.leg.br/proposicoesWeb/prop_mostrarintegra?codteor=1144490\&fil ename=Dossie+-PL+1645/1991. Acesso em: 19 jul. 2019.

BRASIL. Câmara dos Deputados. Projeto de lei. PL 809/1991. Disponível em: https://www.camara.leg.br/proposicoesWeb/prop_mostrarintegra;jsessionid=EA454065 85FE945577BB9BBE2C8E2966.proposicoesWebExterno1?codteor=1144316\&filenam e=Dossie+-PL+809/1991. Acesso em: 19 jul. 2019.

BRASIL. Câmara dos Deputados. Projeto de lei. PL 1645/1991. Disponível em: https://www.camara.leg.br/proposicoesWeb/prop_mostrarintegra?codteor=1144490\&fil ename=Dossie+-PL+1645/1991. Acesso em: 19 jul. 2019.

BRASIL. Câmara dos Deputados. Projeto de lei. PL 1737/1991. Disponível em: https://www.camara.leg.br/proposicoesWeb/prop_mostrarintegra?codteor=1141638\&fil ename=Dossie+-PL+1737/1991. Acesso em: 19 jul. 2019.

BRASIL. Câmara dos Deputados. Projeto de lei. PL 3638/1993. Disponível em: http://imagem.camara.gov.br/Imagem/d/pdf/DCD30MAR1993.pdf\#page=35. Acesso em: 20 jul. 2019.

BRASIL. Câmara dos Deputados. Projeto de lei. PL 6296/2002. Disponível em: https://www.camara.leg.br/proposicoesWeb/prop_mostrarintegra?codteor=1281277\&fil ename=PL+6296/2002. Acesso em: 19 jul. 2019.

BRASIL. Câmara dos Deputados. Projeto de lei. PL 1135/2003. Disponível em: https://www.camara.leg.br/proposicoesWeb/prop_mostrarintegra?codteor=136097\&file name $=P L+1135 / 2003$. Acesso em: 20 jul. 2019.

BRASIL. Câmara dos Deputados. Projeto de lei. PL 1184/2003. Disponível em: https://www.camara.leg.br/proposicoesWeb/prop_mostrarintegra?codteor $=137589 \&$ file name $=P L+1184 / 2003$. Acesso em: 19 jul. 2019.

${ }^{1}$ BRASIL. Câmara dos Deputados. Projeto de lei. PL 2061/2003. Disponível em: https://www.camara.leg.br/proposicoesWeb/prop_mostrarintegra?codteor=166567\&file name=PL+2061/2003. Acesso em: 19 jul. 2019.

BRASIL. Câmara dos Deputados. Projeto de lei. PL 4892/2012. Disponível em: https://www.camara.leg.br/proposicoesWeb/prop_mostrarintegra;jsessionid=A61C326B D8AE11A349044D150C750ACF.proposicoesWebExterno1?codteor=1051906\&filena me=PL+4892/2012. Acesso em: 5 ago. 2019.

BRASIL. Câmara dos Deputados. Projeto de lei. PL 115/2015. Disponível em: https://www.camara.leg.br/proposicoesWeb/prop_mostrarintegra?codteor=1296985\&fil ename $=P L+115 / 2015$. Acesso em: 20 jul. 2019. 
DALSENTER, Thamis; KONDER, Carlos Nelson. Questões atuais da responsabilidade civil médica e hospitalar. In: DADALTO, Luciana; TEIXEIRA, Ana Carolina Brochado (Orgs.). Dos Hospitais aos Tribunais. 1. ed. Belo Horizonte: Del Rey, 2013. p.463498.

LAMM, Eleonora. Gestación por sustitución: ni maternidade subrogada ni alquiler de vientres. Barcelona: Universitat de Barcelona Publicacions i Edicions, 2014.

MALUF, Adriana Caldas do Rego Freitas Dabus. Curso de Bioética e Biodireito. 3. ed. São Paulo: Atlas, 2015.

PEREIRA, Jane Reis Gonçalves. Interpretação Constitucional e Direitos

Fundamentais. 2. ed. São Paulo: Saraiva Educação, 2018.

RODRIGUES, Daiany da Silva et al. A Cessão Temporária do Útero: análise de limitação etária de 50 anos para a cedente. Revista Nacional de Direito de Família e Sucessões, Porto Alegre, n. 21, p.61-79, nov. 2017.

SARMENTO, Daniel. Dignidade da Pessoa Humana: conteúdo, trajetórias e metodologia. 2. ed. Belo Horizonte: Editora Fórum, 2016.

SCHETTINI, Beatriz. Planejamento familiar e a gestação de substituição: os limites ao exercício do direito de procriação. In: RODRIGUES JÚNIOR, Walsir Edson (Org.).

Direito das famílias: novas tendências. Belo Horizonte: D’Plácido, 2015. p. 31-48.

SCHREIBER, Anderson. Manual de Direito Civil Contemporâneo. São Paulo:

Saraiva Educação, 2018. 